\title{
Occupational exposure to polychlorinated biphenyls in electrical workers. I Environmental and blood polychlorinated biphenyls concentrations
}

\author{
M MARONI, ${ }^{1}$ A COLOMBI, ${ }^{1}$ SUSANNA CANTONI, ${ }^{2}$ E FERIOLI, ${ }^{3}$ AND V FOA' \\ From Clinica del Lavoro "L Devoto,"1 University of Milan, Occupational Preventive Medicine \\ Service, ${ }^{2}$ Municipality of Milan, and Laboratory of Hygiene and Prophylaxys, ${ }^{3}$ \\ Province of Milan, Italy
}

ABSTRACT Industrial exposure to polychlorinated biphenyls (PCBs) and internal dose were investigated in 80 workers exposed for many years to PCB mixtures with a $42 \%$ chlorine content (Pyralene 3010 and Apirolio). PCBs were determined by liquid gas chromatography on samples taken from workroom air, workroom surfaces and tools, the palms of the hand, and the blood of the workers. In the workroom air samples, PCB concentrations ranged from 48 to $275 \mu \mathrm{g} / \mathrm{m}^{3}$. All tested surfaces and tools were heavily contaminated, with a range from 0.2 to $159 \mu \mathrm{g}$ PCBs per $\mathrm{cm}^{2}$ of surface. Considerable amounts of PCBs were detected on the palms of the hands of the workers $\left(2-28 \mu \mathrm{g} / \mathrm{cm}^{2}\right.$ of skin surface). In blood, total PCB concentrations from 88 to $1319 \mu \mathrm{g} / \mathrm{kg}$ were observed: comparing the blood concentrations of low and high chlorine content biphenyls, a significant difference was found for the low-chlorinated biphenyl concentrations between workers currently exposed and workers exposed only in the past. In groups of workers who were homogeneous as regards work area and job, the PCB concentrations in the blood were closely correlated with the length of actual occupational exposure to these compounds.

These findings led to the conclusion that absorption of PCBs in these workers had occurred mainly through the skin, and therefore industrial preventive surveillance must take this route of exposure into account. Since blood PCB concentrations appear to be correlated with the length of exposure, PCB determination on whole blood may be used to monitor industrial and environmental exposure to PCBs.

Polychlorinated biphenyls (PCBs) are compounds characterised by long-lasting persistence in the environment; total cumulative world production of PCBs has so far been estimated at around 1 million tons. 1

Commercial production of PCBs began in the USA in 1929 and consumption increased continuously until the early 1970s: the number of occupationally exposed people in the USA has been estimated to be about $12000 .^{2}$ In Italy industrial production began in 1936 and in 1978 reached an

Requests for reprints to: Marco Maroni, MD, Department of Occupational Hygiene and Toxicology, Clinica del Lavoro "L Devoto," University of Milan, via S Barnaba 8, 20122 Milan.

Received 8 November 1979

Accepted 7 March 1980 output of about 5000 tons. In 1973 the following uses of PCBs were recorded: 1230 tons for electric transformers, 1430 tons for large capacitors, 290 tons as plasticisers, and 70 tons as a fire-retardant in plastics $^{3}$; precise information about the number of occupationally exposed workers in Italy is lacking, but it probably exceeds several thousand.

The diffusion of PCBs in the environment has been amply investigated in several countries, ${ }^{13}$ but few data are available on the route of absorption and internal concentrations of occupationally exposed people. ${ }^{4-6}$ In Italy PCB concentrations in the environment and in food have been studied by Leoni et $a l^{7}$ and by Vannucchi et $a l^{8}$

We report the results of an investigation in two plants on pollution of the working environment and internal dose in workers using PCBs as a dielectric. 


\section{Materials and methods}

\section{PLANTS AND POPULATIONS}

Plant A produces electric capacitors filled with mineral oils or polychlorobiphenyl mixtures as dielectric fluid. A PCB mixture with $54 \%$ chlorine (so-called "pentachlorobiphenyl") was used from 1949 to 1965 and subsequently substituted with Pyralene $3010,{ }^{*}$ with a chlorine content of $42 \%$ (so-called "trichlorobiphenyl") and the following average compositions: $9 \%$ dichlorobiphenyls, $60 \%$ trichlorobiphenyls, $30 \%$ tetrachlorobiphenyls, and $1 \%$ pentachlorobiphenyls.

Capacitor manufacture involves three departments:

High-power capacitor department-Here all the capacitors are impregnated by filling the casing with the dielectr ic fluid. Filling with PCBs is done in autoclaves at around $70^{\circ} \mathrm{C}$ and lasts for several hours; after cooling to $40-50^{\circ} \mathrm{C}$ the autoclaves are emptied and the capacitors are taken out by hand. In this department the high power capacitors are also closed by welding, tested, and finished externally.

Low-power capacitor department-Here the lowpower capacitors are assembled, sent to dielectric impregnation, and then closed, washed, tested, and finished externally.

Electric "filters" department-Here the filters (small capacitor systems used in electrical household appliances) are assembled, sent to dielectric impregnation, and finally closed, washed, tested, and finished externally.

Sixty-seven workers (40 female, 27 male) were examined: 48 were currently employed in these departments, 16 had been employed there only in the past (at least six months before the beginning of the study), and three had always been employed in other departments, where there was no direct exposure to PCBs, except by occasionally passing through the contaminated departments.

Plant $\mathbf{B}$ is an experimental centre: the work consists of short circuit testing of high-power capacitors filled with Apirolio, $\uparrow$ a PCB mixture with $42 \%$ chlorine. In this plant all workers (13 men) engaged on capacitor testing were studied: they were exposed to PCBs during handling of the capacitors contaminated with Apirolio, dispersed from explosions sometimes caused by stress in testing.

EVALUATION OF PCB EXPOSURE AND

INTERNAL DOSE IN WORKERS

The mean age $( \pm S D)$ and length of employment of the 80 workers under study were respectively $37 \pm 8$ and $12 \pm 6$ years.

*Prodelec-France.

†Caffaro-Italy.
Sample preparation

Samples of air of the working environment were passed through a Greenburg-Smith impinger containing a mixture of diethylene glycol and diethylene glycolmonobutylether $(1: 1 \mathrm{vol} / \mathrm{vol})$. The solvent mixture was repeatedly extracted with petroleum ether (bp $40-60^{\circ} \mathrm{C}$ ) and analysed for PCB content.

Samples from working surfaces in the environment - that is, the work table, tools, and palms of the workers' hands-were prepared by cleaning the tested surfaces with a hexane-washed cotton wool plug imbued with a mixture of petroleum ether and acetone $(4: 1 \mathrm{vol})$ : the plugs were afterwards extracted with petroleum ether and analysed.

Samples of heparinised blood $(5 \mathrm{ml})$ collected with a glass syringe (washed with hexane) were added to $10 \mathrm{ml}$ of distilled water. The mixture was allowed to stand for at least $15 \mathrm{~min}$ (during which time hemolysis occurred) and was then repeatedly extracted with hexane $(3 \times 5 \mathrm{ml})$ in the presence of magnesium sulphate. The hexane was dehydrated, concentrated, and purified before analysis. Samples of serum were treated in the same manner.

\section{Determination of PCBs}

Sample cleaning and liquid gas chromatography determination of PCBs were carried out using the method of Armour and Burke ${ }^{9}$ as amended by the Food and Drug Administration. ${ }^{10}$

Quantification was achieved by measuring the areas of all the PCB peaks compared with the areas of known amounts of a standard PCB mixture in hexane. For samples with the simultaneous presence of low and high chlorinated biphenyls, there was an overlap in the chromatograms of the peaks attributable to standard mixtures with $42 \%$ and $54 \%$ chlorine: since in a standard mixture with $42 \%$ chlorine the ratio of the highest peak and the last detectable peak is $100: 5$, all the peaks in the overlapping region with a ratio greater than 100:10 were attributed to the mixture with $54 \%$ chlorine. Low and high chlorine content peaks are expressed as TRI-CB and PENTA-CB respectively.

Some chromatographic peaks obtained from blood samples were attributed to PCB compounds after confirmation with mass-spectrometry.

\section{Results}

PRESENCE OF PCBS IN THE ENVIRONMENT Airborne concentrations of PCB in the three departments of plant A where PCBs are used are shown in table 1.The PCBs detected in the air samples showed the typical gas chromatographic pattern of a trichlorobiphenyl mixture, without any enrichment of higher chlorine compounds. Concentrations in the 
Table $1 \quad P C B$ concentrations in air of workrooms in plant $A$

\begin{tabular}{llc}
\hline Department & \multicolumn{2}{l}{ Trichlorobiphenyl compounds $\left(\mu \mathrm{g} / \mathrm{m}^{3}\right)$} \\
\cline { 2 - 3 } & Mean & Range \\
\hline $\begin{array}{l}\text { High-power capacitors } \\
\text { (4 samples) }\end{array}$ & 154 & $80-255$ \\
$\begin{array}{l}\text { Low-power capacitors } \\
\text { (3 samples) }\end{array}$ & 193 & $149-275$ \\
Filters & 59 & $48-70$ \\
(2 samples) & & \\
\hline
\end{tabular}

capacitor departments were similar to each other but lower concentrations were found in the filters department.

Table 2 gives the results obtained from PCB determinations on workroom surfaces and tools. The PCBs detected showed the gas chromatographic pattern typical of both trichlorobiphenyl and pentachlorobiphenyl mixtures. The results obtained from PCB determination on the palms of the hand of six workers are shown in table 3: the gas chromatographic peaks of recovered PCBs were typical of a mixed pattern of trichlorobiphenyls and pentachlorobiphenyls.
INTERNAL LEVEL OF PCBS IN WORKERS

Studies of the extraction and cleaning procedure on whole blood samples showed that recovery was about $80 \%$. An analytical comparison between the PCB concentrations measured in the serum and whole blood of 18 workers showed a mean PCB recovery from serum of about $60 \%$ of the recovery from whole blood, with a wide range among the samples (recovery range for total chlorobiphenyls $8-83 \%$ ). Blood PCB determinations were therefore performed on whole blood and the results are reported in table 4.

Statistical evaluation of the results from plant A indicated a significant difference $(p<0.05)$ for blood trichlorobiphenyl concentrations between current and past exposed workers; no significant difference was found for blood pentachlorobiphenyl concentrations. A pronounced difference was also evident for the blood PCB concentrations between the workers employed in the three PCB departments and those with indirect exposure.

Since the length of employment did not reflect the real duration of exposure to PCBs for the workers of plant A, a detailed analysis was performed to evaluate the different jobs and all manufacturing operations affecting direct exposure to PCBs carried out daily by the workers. By multiplying the length

Table $2 \quad P C B$ recovery from workroom surfaces and tools in plant $A$

\begin{tabular}{|c|c|c|c|}
\hline Source & $\begin{array}{l}\text { TRI-CB components } \\
(\mu \mathrm{g})\end{array}$ & $\begin{array}{l}\text { PENTA-CB components } \\
(\mu g)\end{array}$ & $\begin{array}{l}\text { TOTAL-CB components } \\
\left(\mu \mathrm{g} / \mathrm{cm}^{2} \text { surface }\right)\end{array}$ \\
\hline \multicolumn{4}{|l|}{ High-power capacitor department } \\
\hline Impregnated capacitor conveyor belt (border) & 1330 & 882 & 0.492 \\
\hline Trolley handle & 760 & 243 & 1.673 \\
\hline Exit-door (inside) & 367 & 66 & 0.541 \\
\hline \multicolumn{4}{|l|}{ Low-power capacitor department } \\
\hline Capacitor basket rolling carrier (beginning) & 127000 & 15000 & 159 \\
\hline Capacitor basket rolling carrier (end) & 2530 & 1290 & $1 \cdot 260$ \\
\hline Capacitor basket lateral surface (outside) & 1770 & - & 0.885 \\
\hline $\begin{array}{l}\text { Capacitor basket lateral surface after } \\
\text { trichloroethylene washing }\end{array}$ & 650 & - & $0 \cdot 323$ \\
\hline $\begin{array}{l}\text { Capacitor external surface after trichloroethylene } \\
\text { washing }\end{array}$ & 250 & - & 0.615 \\
\hline \multicolumn{4}{|l|}{ Filters department } \\
\hline Work table & 1240 & 780 & 0.404 \\
\hline Work table drawer and drawer handle & 156 & 407 & $1 \cdot 061$ \\
\hline Pincers & 105 & 30 & - \\
\hline $\begin{array}{l}\text { Filter basket lateral surface after } \\
\text { trichloroethylene washing }\end{array}$ & 30 & 10 & $0 \cdot 200$ \\
\hline Washing-machine control panel & 187 & 505 & $0 \cdot 288$ \\
\hline Lift handle & 223 & 151 & $6 \cdot 170$ \\
\hline
\end{tabular}

Table $3 P C B$ recovery from the palms of hands of workers in plant $A$

\begin{tabular}{|c|c|c|c|c|}
\hline Department & & $\begin{array}{l}\text { TRI-CB } \\
\text { components }\end{array}$ & $\begin{array}{l}\text { PENTA-CB } \\
\text { components }\end{array}$ & $\begin{array}{l}\text { TOTAL-CB } \\
\left(\mu \mathrm{g} / \mathrm{cm}^{2} \text { skin surface }\right)\end{array}$ \\
\hline $\begin{array}{l}\text { High-power capacitors } \\
\text { ( } 3 \text { subjects) } \\
\text { Low-power capacitors } \\
\text { ( } 3 \text { subjects) }\end{array}$ & $\begin{array}{l}\text { Mean } \\
\text { Range } \\
\text { Meari } \\
\text { Range }\end{array}$ & $\begin{array}{c}1267 \\
320-1770 \\
589 \\
160-1590\end{array}$ & $\begin{array}{l}282 \\
200-364 \\
223 \\
0-630\end{array}$ & $\begin{array}{c}19 \\
4-27 \\
10 \\
2-28\end{array}$ \\
\hline
\end{tabular}


Table 4 Blood PCB concentrations in workers according to plant and exposure

\begin{tabular}{|c|c|c|c|c|c|c|}
\hline & \multicolumn{3}{|c|}{ Plant A (Pyralene 3010) } & \multicolumn{3}{|c|}{ Plant B (Apirolio) } \\
\hline & $\begin{array}{l}\text { TRI-CB } \\
\text { components } \\
(\mu g / k g) \\
\text { Mean } \pm S D \\
\text { range }\end{array}$ & $\begin{array}{l}P E N T A-C B \\
\text { components } \\
(\mu g / k g) \\
\text { Mean } \pm S D \\
\text { range }\end{array}$ & $\begin{array}{l}T O T A L-C B \\
(\mu g / k g) \\
\begin{array}{l}\text { Mean } \pm S D \\
\text { range }\end{array}\end{array}$ & $\begin{array}{l}\text { TRI-CB } \\
\text { components } \\
(\mu g / k g) \\
\text { Mean } \pm S D \\
\text { range }\end{array}$ & $\begin{array}{l}P E N T A-C B \\
\text { components } \\
(\mu g / k g) \\
\text { Mean } \pm S D \\
\text { range }\end{array}$ & $\begin{array}{l}\text { TOTAL-CB } \\
(\mu g / k g) \\
\text { Mean } \pm S D \\
\text { range }\end{array}$ \\
\hline $\begin{array}{l}\text { Currently exposed workers } \\
\text { Plant } A, n=48 \\
\text { Plant } B, n=12\end{array}$ & $\begin{array}{c}128 \pm 85 \\
13-355\end{array}$ & $\begin{array}{c}249 \pm 190 \\
56-1032\end{array}$ & $\begin{array}{c}377 \pm 258 \\
88-1319\end{array}$ & $\begin{array}{l}137 \pm 123 \\
17-407\end{array}$ & $\begin{array}{l}62 \pm 50 \\
15-176\end{array}$ & $\begin{array}{l}200 \pm 146 \\
41-470\end{array}$ \\
\hline $\begin{array}{l}\text { Past exposed workers } \\
\text { Plant } A, n=16 \\
\text { Plant } B, n=1\end{array}$ & $\begin{array}{l}86 \pm 50 \\
16-184\end{array}$ & $\begin{array}{l}206 \pm 123 \\
73-489\end{array}$ & $\begin{array}{c}292 \pm 161 \\
94-631\end{array}$ & 74 & 30 & 104 \\
\hline $\begin{array}{l}\text { Workers with occasional exposure } \\
\text { Plant } \mathbf{A}, \mathbf{n}=3\end{array}$ & $\begin{array}{l}37 \pm 23 \\
18-63\end{array}$ & $\begin{array}{l}73 \pm 13 \\
58-83\end{array}$ & $\begin{array}{c}110 \pm 31 \\
88-146\end{array}$ & - & - & - \\
\hline
\end{tabular}

Table 5 Blood PCB concentrations in plant $A$ workers according to job

\begin{tabular}{|c|c|c|c|c|c|c|c|}
\hline Department & $J o b$ & $\begin{array}{l}\text { No of } \\
\text { workers }\end{array}$ & $\begin{array}{l}\text { Age }(y r) \\
\text { Mean } \pm S D\end{array}$ & $\begin{array}{l}\text { Duration of } \\
\text { exposure index } \\
\text { Mean } \pm S D\end{array}$ & $\begin{array}{l}\text { Blood TRI-CB } \\
\text { components } \\
(\mu \mathrm{g} / \mathrm{kg}) \\
\text { Mean } \pm S D\end{array}$ & $\begin{array}{l}\text { Blood PENTA-CB } \\
\text { components } \\
(\mu g / k g) \\
\text { Mean } \pm S D\end{array}$ & $\begin{array}{l}\text { Blood TOTAL-CB } \\
(\mu \mathrm{g} / \mathrm{kg}) \\
\text { Mean } \pm S D\end{array}$ \\
\hline $\begin{array}{l}\text { High-power } \\
\text { capacitors }\end{array}$ & $\begin{array}{l}\text { Impregnation } \\
\text { Assembling } \\
\text { Welding }\end{array}$ & $\begin{array}{l}9 \\
5 \\
1\end{array}$ & $\begin{array}{l}50 \pm 4 \\
34 \pm 6 \\
26\end{array}$ & $\begin{array}{l}8 \cdot 0 \pm 4 \cdot 9 \\
1 \cdot 7 \pm 1 \cdot 3 \\
0 \cdot 3\end{array}$ & $\begin{array}{l}187 \pm 94 \\
168 \pm 78 \\
227\end{array}$ & $\begin{aligned} 369 & \pm 256 \\
238 & \pm 97 \\
1032 & \end{aligned}$ & $\begin{array}{r}556 \pm 337 \\
406 \pm 173 \\
1259\end{array}$ \\
\hline $\begin{array}{l}\text { Low-power } \\
\text { capacitors }\end{array}$ & $\begin{array}{l}\text { Assembling and } \\
\text { finishing }\end{array}$ & 18 & $36 \pm 8$ & $1 \cdot 1 \pm 1 \cdot 5$ & $130 \pm 84$ & $231 \pm 119$ & $361 \pm 189$ \\
\hline Filters & $\begin{array}{l}\text { Assembling and } \\
\text { finishing }\end{array}$ & 13 & $33 \pm 4$ & $4 \cdot 4 \pm 3 \cdot 4$ & $64 \pm 42$ & $182 \pm 95$ & $246 \pm 130$ \\
\hline $\begin{array}{l}\text { General } \\
\text { maintenance }\end{array}$ & $\begin{array}{l}\text { Machine } \\
\text { servicing }\end{array}$ & 4 & $39 \pm 9$ & $1 \cdot 6 \pm 1 \cdot 0$ & $139 \pm 33$ & $261 \pm 81$ & $400 \pm 114$ \\
\hline
\end{tabular}

of employment (in years) by the percentage ratio of the hours a year actually spent with direct exposure to PCBs, an index was constructed as follows:

Duration of exposure index $=\mathrm{yr}_{\mathrm{E}} \times \frac{\mathrm{hr}_{\mathrm{PCBS}}}{\mathrm{hr}_{\mathrm{tot}}} \times 100$

In table 5 the blood PCB concentrations of plant A workers are reported according to department and job: 14 workers were omitted because they had been engaged in more than one task so that it was impossible to assign them to a definite group.

Figures 1 and 2 are scatter diagrams of blood PCB concentrations and duration of exposure indices for the workers employed respectively in the low-power capacitor department and in the filters department.

If the currently exposed and past exposed workers (empty and full circles in the figures) are considered separately, a higher pentachlorobiphenyl blood concentration for the workers exposed only in the past may be clearly observed.

\section{Discussion}

Occupational exposure to PCBs is at present one of the most important problems for the electric high power capacitor and transformer industry, where technologically it will be difficult to replace these substances in the short term. In our study, for plant
A, air concentrations of PCBs from 48 to $275 \mu \mathrm{g} / \mathrm{m}^{3}$ were observed, which are well below the limit of $1 \mathrm{mg} / \mathrm{m}^{3}$ internationally accepted for the chlorobiphenyls with $42 \%$ chlorine content. ${ }^{11}$ Conversely, the high concentrations detected on surfaces (see table 2) indicated that this source of exposure may be the most important due to absorption through the skin.

With regard to the gaschromatographic pattern of PCBs detected in the working environment, the air samples showed only the presence of components with relatively high volatility-that is, the lowchlorinated biphenyls - while significant amounts of pentachlorobiphenyls were often detected on surfaces; considering the low content of high chlorinated biphenyl in the mixture used (Pyralene 3010), these findings seem to confirm that the high chlorinated biphenyls tend to accumulate in the environment because of a lower natural and artificial removal rate.

The existence of a percutaneous absorption risk was also emphasised by the determinations performed on the palms of the hands of the workers, where considerable amounts of PCBs were detected in all subjects tested. Since the possibility of percutaneous absorption of PCBs has been shown experimentally, ${ }^{12}$ it must be concluded that in these workers percutaneous absorption of PCBs is far greater than 


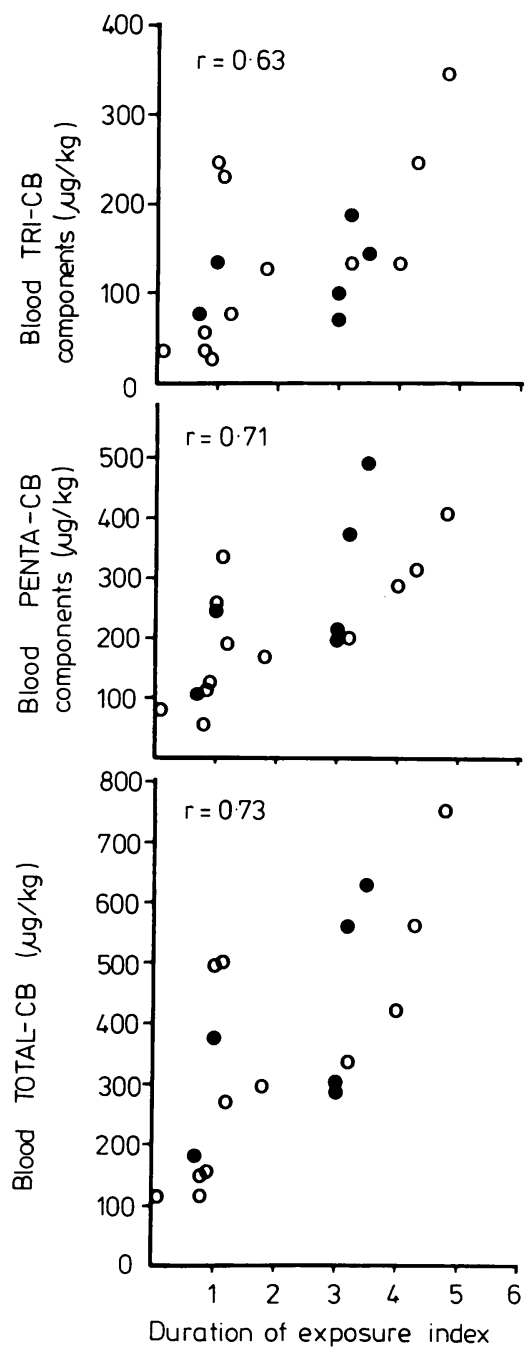

Fig 1 Blood PCB concentrations in workers of low-power capacitor department in relation to exposure duration indices $(\bigcirc=$ currently exposed workers; = past exposed workers).

by inhalation.

The blood PCB concentrations measured in the exposed workers of plants A and B (table 4) are of the same order of magnitude as those reported by other authors ${ }^{4-6}$ for similar electrical engineering works.

In plant $\mathrm{A}$ workers the mean blood concentration of pentachlorobiphenyl compounds was higher than that of trichlorobiphenyls, while the reverse occurred in plant B workers; as the PCB mixture used in the two plants was about the same in chlorine content, this unexpected blood PCB pattern of plant A

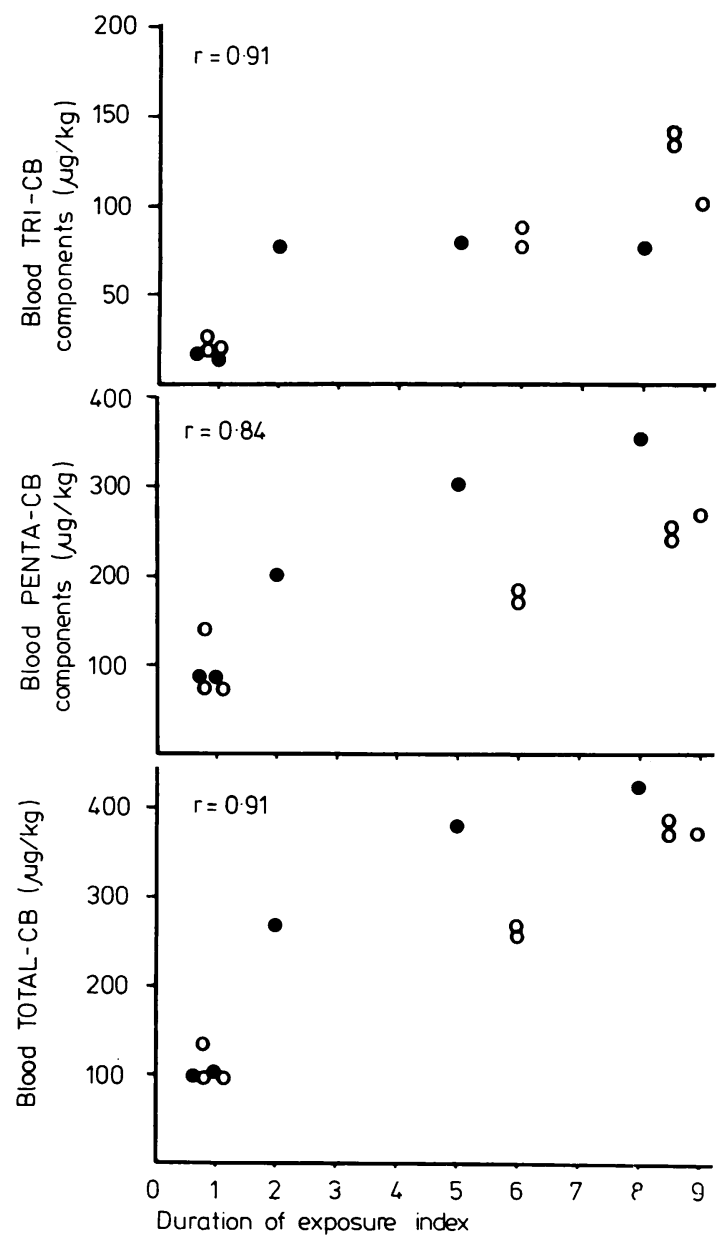

Fig 2 Blood PCB concentrations in workers of filters department in relation to exposure duration indices $(\mathrm{O}=$ currently exposed workers; $\bigcirc=$ past exposed workers).

workers might be due partly to a heavy past exposure to the highly chlorinated mixture used up to 1965 .

The comparison of mean blood PCB concentrations between current and past exposed workers of plant A (table 4) showed a significant difference only for trichlorobiphenyl levels, but a pronounced difference was observed, both for trichloro- and pentachlorobiphenyl, between the workers with direct (current and past) and occasional exposure.

Since it is common knowledge that PCBs are slowly metabolised and eliminated from the body ${ }^{13}$ we looked for a correlation between blood PCB concentrations and duration of exposure, using a more exact duration of exposure index instead of 
duration of employment. This correlation was strongly positive in groups of workers with similar jobs (figs 1 and 2) and confirms that PCBs accumulate in the organism.

\section{Conclusions}

In the plants under study absorption of PCBs occurred mainly through the skin, so the commonly used method to assess industrial exposure of determining the atmospheric PCB concentration is not sufficient to give complete information on the exposure level of the workers. Guidelines for preventing undue exposure in industry must consider the protection against skin absorption.

The determination of PCBs in whole blood has been shown to be a useful test to evaluate in monitoring the body burden. The blood PCB concentration evaluated with reference to the duration of exposure may be used to compare different levels of occupational and environmental exposure.

In workers exposed to PCB mixtures with $42 \%$ chlorine, the blood concentration of low chlorinated biphenyls (TRI-CB) may be roughly indicative of the recent exposure, while the blood concentration of high chlorinated biphenyls (PENTA-CB) reflects more closely the earlier exposure.

\section{References}

1 World Health Organisation. Polychlorinated biphenyls and terphenyls. Geneva: WHO, 1976. (Environmental health criteria No 2.)
2 Lloyd JW, Moore RM, Wolff BS, Stein MP. Polychlorinated biphenyls. JOM 1976;18:109-13.

3 International Agency for Research on Cancer. Polychlorinated biphenyls and polybrominated biphenyls. In: Monographs on the evaluation of the carcinogenic risk of chemicals to humans. Vol 18. Lyon: IARC, 1978.

${ }^{4}$ Karppanen E, Kolho $L$. The concentrations of PCB in human blood and adipose tissue in three different research groups. In: Proceedings of the 2nd PCB Conference, Solna, Sweden, 1972. Stockholm: National Swedish Environmental Protection Board, 1973:124-8.

${ }^{5}$ Ouw HK, Simpson GR, Siyali DS. Use and health effects of Aroclor 1242, a polychlorinated biphenyl, in an electrical industry. Arch Environ Health 1976;31:189-94.

${ }^{6}$ Wolff MS. Serum analysis for halogenated biphenyls among occupationally exposed persons. In: Plestina R, ed. Abstracts XIX International Congress for Occupational Health. Zagreb: Institute for Medical Research and Occupational Health, 1978.

${ }^{7}$ Leoni V, Boniforti L, Simeone AM, Caratozzulo C, Puccetti G, Biagini F. Sulla contaminazione da policlorodifenili di campioni di alimenti e di acque superficiali in Italia. Indagini preliminari effettuate per gas cromatografia-spettrometria di massa. Nuovi Ann Ig Microbiol $1971 ; 22: 185-218$.

${ }^{8}$ Vannucchi C, Ghimenti G, Taponeco G. Sulla contaminazione degli alimentati da pestici organo-clorurati e da PCB. Rivista della Societá Italiana dı Scienze Alimentari 1973;2:71-103.

9 Armour JA, Burke JA. Method for separating polychlorinated biphenyls from DDT and its analogs. $J$ Assoc Off Anal Chem 1970;53:761-8.

${ }^{10}$ Food and Drug Administration. Pesticide analytical manual. Vol I. Washington: US Department of Health, Education and Welfare, 1968.

11 Institute National de Recherche et de Sécurité. Valeurs limites de concentration des substances toxiques dans l'air. Cahiers de notes documentaires 1976;82:77-104.

12 Nishizumi M. Radioautographic evidence for absorption of polychlorinated biphenyls through the skin. Industrial Health 1976;14:41-4. 